BRES 16629

\title{
Oleic acid reversibly opens the blood-brain barrier
}

\author{
László Sztrıha ${ }^{1,4}$ and A. Lorrıs Betz ${ }^{1-3}$ \\ Departments of ${ }^{1}$ Surgery, ${ }^{2}$ Pediatrics and ${ }^{3}$ Neurology, University of Michtgan, Ann Arbor, MI 48109 (US A) and ${ }^{4}$ Department of \\ Pediatrics, Szent-Gyorgyt Medical School, Szeged (Hungary)
}

(Accepted 18 December 1990)

Key words Oleıc acıd, Blood-brain barner, $\alpha$-Amınoısobutync acıd permeabılity surface area product, Permeabılıty, Barrier modıfication

\begin{abstract}
This study examıned the effect of intracarotıd oleic acid infusion on blood-brain barrier permeability Oleic acid was infused for $30 \mathrm{~s}$ at a rate of $6 \mathrm{ml} / \mathrm{min}$ into the night internal carotid artery at concentrations of $10^{-6}, 10^{-5}, 2 \times 10^{-5}$ and $5 \times 10^{-5} \mathrm{M}$ Extensive Evans blue-albumin extravasation was observed $15 \mathrm{~min}$ after the administration of $2 \times 10^{-5} \mathrm{M}$ oleic acid The permeability surface area product for $\alpha$-amınoisobutync acid (AIB), determined 1-11 min following the infusion of oleic acid was increased 10 -fold following infusion of $10^{-5} \mathrm{M}$ oleic acid and 20-fold following the administration of $5 \times 10^{-5} \mathrm{M}$ oleate The blood-brain barner opening to AIB proved to be reversible $80-90 \mathrm{~min}$ after the infusion of $2 \times 10^{-5} \mathrm{M}$ oleic acid The possible mechanisms of the oleic acid effect are discussed
\end{abstract}

\section{INTRODUCTION}

The capillaries in brain are formed by a specialized endothelium whose function is to regulate the movement of solutes between blood and brain The endothelial cells in brain capillaries are sealed together by contınuous tight junctions and contain few pincytotic vesicles These properties limit the free exchange of water-soluble non-electrolytes, electrolytes and proteıns from blood to brain and are responsible for formation of a blood-brain barner (BBB) $)^{6.25} 27$

Since brain uptake of many neuropharmacologic agents is limited by the BBB, a method for reversibly increasing cerebrovascular permeability could enhance treatment of a variety of neurologic diseases Osmotic BBB openıng has been characterized quantitatıvely and shown to be reproducible and reversible ${ }^{23}$ It is believed to increase BBB permeability by disruptıng intracellular tıght junctions ${ }^{4}$ Clinically, this procedure has been shown to increase the delivery of chemotherapeutic agents to the brain ${ }^{17}$, but its use for treatment of patients is not yet widely accepted ${ }^{57}$

Alternative approaches to increasing BBB permeability would be to alter endothelial cell membrane integrity or to activate intracellular second messenger systems that regulate BBB permeability In recent years, there have been many studies on the biological effects of the fatty acids $^{31113,1418,2029}$ and there is growing evidence that they modify membrane structure and function ${ }^{26}$ Low concentrations of several unsaturated fatty acids such as oleic, linoleic and linolenic acid exert a stabilizing effect on the erythrocyte membrane, whereas higher concentrations of these same agents cause membrane lysis ${ }^{26}$ Furthermore, protein kinase $\mathrm{C}$, an enzyme which can be detected in brain capillanes ${ }^{22}$ and plays an important role in the regulation of cellular functions ${ }^{16}$, is activated by unsaturated fatty acids ${ }^{13,14}$ Liberation of vanous free fatty acids from brain tissue has been observed during injuries that are associated with BBB opening, such as ischemi ${ }^{15}$ and cold injury ${ }^{1}$ Much attention has been focused on the role of arachidonic acid and less on the other unsaturated fatty acids as possible contributing agents in the BBB destruction and brain edema formation that accompanies these injuries ${ }^{3,29}$ In this study, we determined the effect of an intracarotid infusion of sodium oleate on BBB permeabılity

\section{MATERIALS AND METHODS}

Adult male Sprague-Dawley rats, weighing between 350 and 400 $\mathrm{g}$ were anesthetized by intramuscular injection of $50 \mathrm{mg} / \mathrm{kg}$ ketamine hydrochloride and $10 \mathrm{mg} / \mathrm{kg}$ xylazıne Polyethylene catheters (PE50) filled with heparinized salıne were inserted into the right femoral vein for the administration of the tracers and into the femoral arteries for contınuous pressure recording and blood sampling After exposure of the right carotid artery, the occipital, superior thyroid and pterygopalatine arteries were ligated, and the right external carotid artery was catheterized for retrograde infusion

Oleic acid sodium salt (Sigma, St Louis, MO) was dissolved in $20 \%$ ethanol and diluted in salıne to concentrations of $10^{-6}, 10^{-5}$, $2 \times 10^{-5}$ and $5 \times 10^{-5} \mathrm{M}$ The stock solutions were prepared at various concentrations so that the final amount of ethanol was the same in each dilution (0004\% ethanol) The osmolality of the 
solutions was between 270 and $290 \mathrm{mOsm}$ and the $\mathrm{pH}$ was adjusted to 74 with sodium hydroxide The oleic acid was infused into the right internal carotid artery at a rate of $6 \mathrm{ml} / \mathrm{mm}$ for 30 , This rate of infusion visibly cleared the internal carotid artery of blood The control rats were infused with salıne, $\mathrm{pH} 74$, containing the same amount of ethanol as the oleic acid solutions

A $2 \mathrm{ml} / \mathrm{kg} \mathrm{b}$ wt dose of Evans blue (2\% $\mathrm{g} / \mathrm{vol})$ solution was injected intravenously in a group of 5 rats, $30 \mathrm{~min}$ before the intracarotid infusion of $2 \times 10^{-5} \mathrm{M}$ oleic acid The anımals were decapitated $15 \mathrm{~min}$ after the carotid infusion and brains were removed, slıced and examıned visually for Evans blue extravasation This quantity of dye binds almost completely to plasma dlbumın and as a dye-proten complex is a qualitatıve marker of BBB integrity ${ }^{24}$

The permeability of cerebral blood vessels to $\left[{ }^{3} \mathrm{H}\right]$ amınossobutyric acid (AIB) ${ }^{2}$ was examined by a modification of the method of Ohno et al ${ }^{14}$ as described previously ${ }^{12}$ A $01 \mathrm{ml}$ salıne bolus containing $45 \mu \mathrm{C}_{1}\left[{ }^{3} \mathrm{H}\right] \mathrm{AIB}$ (DuPont/NEN, Boston, MA) was injected into the femoral vein and allowed to circulate for 10 min During this time, blood was continuously withdrawn from a femoral arterv into polyethylene tubing At the end of the 10 min circuldtion time, a blood sample was taken from the other femoral artery cannula to determine the final plasma isotope concentrations and hematocrit The anımal was then decapitated and the brain removed The brain was dissected into right and left halves and then the anterior and posterior cortex, hippocampus, basal ganglia, cerebellar hemıspheres and brainstem were separated These tıssues were dissolved in Protosol (DuPont/NEN, Boston, MA) Aliquots of plasma from the terminal blood sample were dissolved in Protosol and alıquots of the continuously withdrawn blood sample were dissolved in Protosol ethanol $(21 \mathrm{v} / \mathrm{v})$ Samples were counted in a two-channel liquid scintillation counter

For $\left[^{2} \mathrm{H}\right] \mathrm{AIB}$, brain uptake can be expressed as the permeability surface area (PS) product according to

$$
\mathrm{PS}=C_{\mathrm{ev}} / \int C_{\mathrm{d}} d t
$$

where $C_{\mathrm{ev}}$ is the amount of extravascular tracer in the brain and $C_{\mathrm{a}}$ is the arterial plasma concentration The integral of $C_{\mathrm{d}}$ with time was calculated from the amount of isotope in the continuously withdrawn arterial blood sample $\left(C_{\mathrm{o}}\right)$, the withdrawal rate $\left(F_{\mathrm{o}}\right)$ and the arterial hematocrit (Hct)

$$
\int C_{d} d t=C_{o}(1-\mathrm{Hct}) / F_{\mathrm{o}}
$$

The amount of extravascular tracer in the brain, $C_{\mathrm{ev}}$, was calculated from the total bran radioactivity minus the terminal plasma concentration of $\left[{ }^{3} \mathrm{H}\right]$ AIB multiplied by the plasma volume For the determination of the regional plasma volumes, $15 \mu \mathrm{Cl}$ $\left[{ }^{14} \mathrm{C}\right]$ dextran (DuPont/NEN, Boston, MA) was injected via the femoral vein $3 \mathrm{~min}$ before the anımal was decapitated The plasma volume of the brain $(\mathrm{ml} / \mathrm{g})$ is equal to the ratio of the ${ }^{14} \mathrm{C}$-counts in brain (per g) and plasma (per $\mathrm{ml}$ )

The $\left[{ }^{3} \mathrm{H}\right]$ AIB was given $1 \mathrm{~min}$ after completion of the carotid infusion of $10^{-6}, 10^{-5}, 2 \times 10^{-5}, 5 \times 10^{-5} \mathrm{M}$ oleic acid One group of rats that received $2 \times 10^{-5} \mathrm{M}$ oleic acid was injected with [ ${ }^{3} \mathrm{H}$ ]AIB $80 \mathrm{~mm}$ after the carotid infusion to examine the reversibility of the blood-brain barrier opening Five rats were used in the control and each experimental group The analysis of variance employing Dunnet's test was used for the statistical comparisons of experimental and control groups

\section{RESULTS}

The physiological parameters are summarızed in Table I There were no differences among the groups in the mean arterial blood pressure (MABP), arterıal $\mathrm{pH}$, $p \mathrm{CO}_{2}, p \mathrm{O}_{2}$ or hematocrit Anımals survived the higher doses of oleic acid for up to $2 \mathrm{~h}$ without obvious detrimental effects

The most pronounced Evans blue extravdsation tollowing infusion at $2 \times 10^{-5} \mathrm{M}$ oleic acid (Fig 1) was observed in the right cortical areas and hippocampus and the left parasagittal cortical area Occasionally Evan blue stainıng appeared in the right cerebellar hemisphere Within a given brain region, the pattern of Evans blue extravasation showed a somewhat heterogeneous distribution

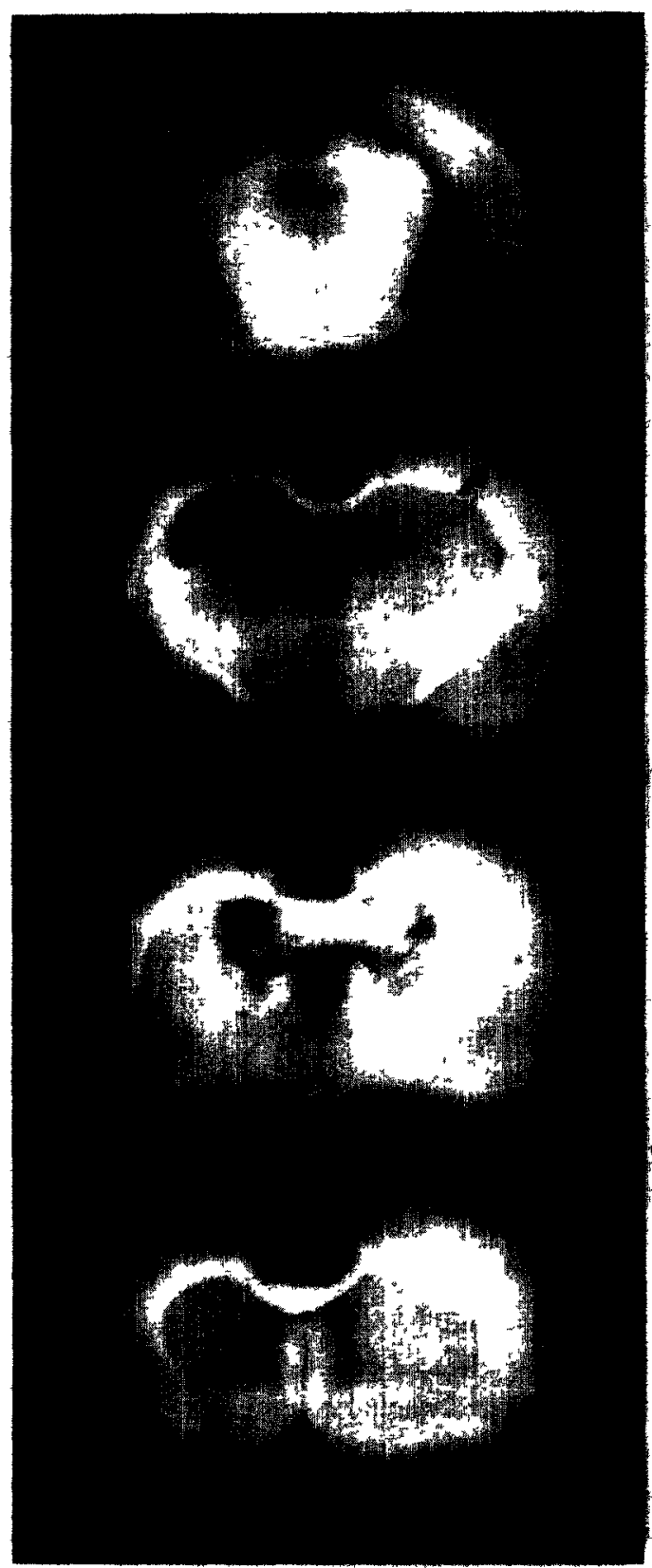

Fig 1 Evans blue extravasation 15 mın after right sided intracarotid Infusion of $2 \times 10^{-5} \mathrm{M}$ oleic acid The appearance of the Evans blue staining is heterogeneous, with pronounced staining in the right cortical and hippocampal areas and the left parasagittal cortical areas 


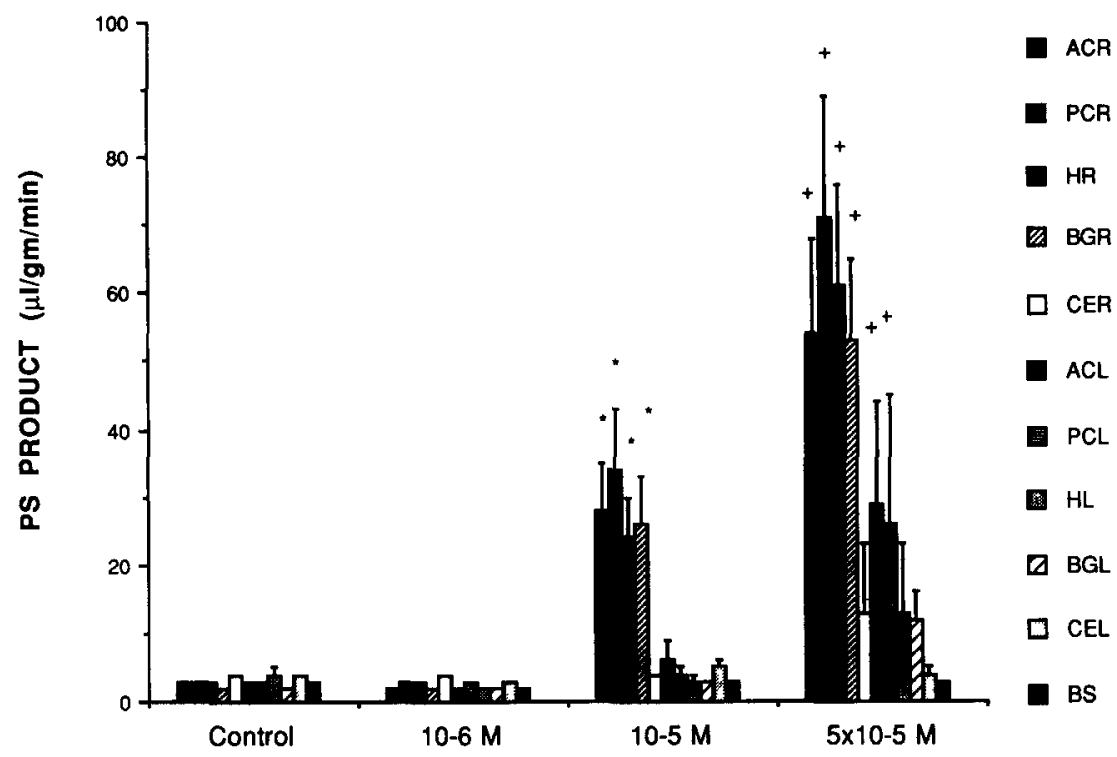

Fig 2 Effect of different concentrations of oleic acid on BBB permeability to AIB Between 1 and 11 min following the infusion of $10^{-5} \mathrm{M}$ oleic acid there was a 10-fold increase in the AIB PS product of the infused hemisphere After $5 \times 10^{-5} \mathrm{M}$ oleate, a further increase was observed ACR, PCR, HR, BGR, CER right sided anterior and posterior cortex, hippocampus, basal ganglia and cerebellum, respectively ACL, PCL, HL, BGL, CEL similar but on the left side BS brainstem Data points represent the means $\pm \mathrm{S} E \mathrm{M}$ of 5 rats in each group ${ }^{*} P<005,{ }^{* *} P<001$ compared with the controls and $10^{-6} \mathrm{M}$ oleate ${ }^{+} P<005,{ }^{++} P<001$ compared with $10^{-5} \mathrm{M}$ oleate

The $\left[{ }^{3} \mathrm{H}\right] \mathrm{AIB}$ PS product vaned between 2 and 4 $\mu \mathrm{l} / \mathrm{g} / \mathrm{min}$ in the brain regions of the salıne-perfused control rats ( $\left.\mathrm{F}_{1} \mathrm{~g} 2\right)$ These values are similar to those reported previously for normal rat brain ${ }^{12}$ and indicate that the sudden perfusion of the rat brain with saline does not, by itself, cause the BBB to open No change was observed after infusion of $10^{-6} \mathrm{M}$ oleic acid, but a significant, 10-fold increase was measured in the areas of the right hemisphere after the administration of $10^{-5} \mathrm{M}$ oleic acid (Fig 2) A further two-fold increase in the $\left[{ }^{3} \mathrm{H}\right] \mathrm{AIB}$ PS product in the right sided brain regions and a significant increase in the right cerebellar hemisphere

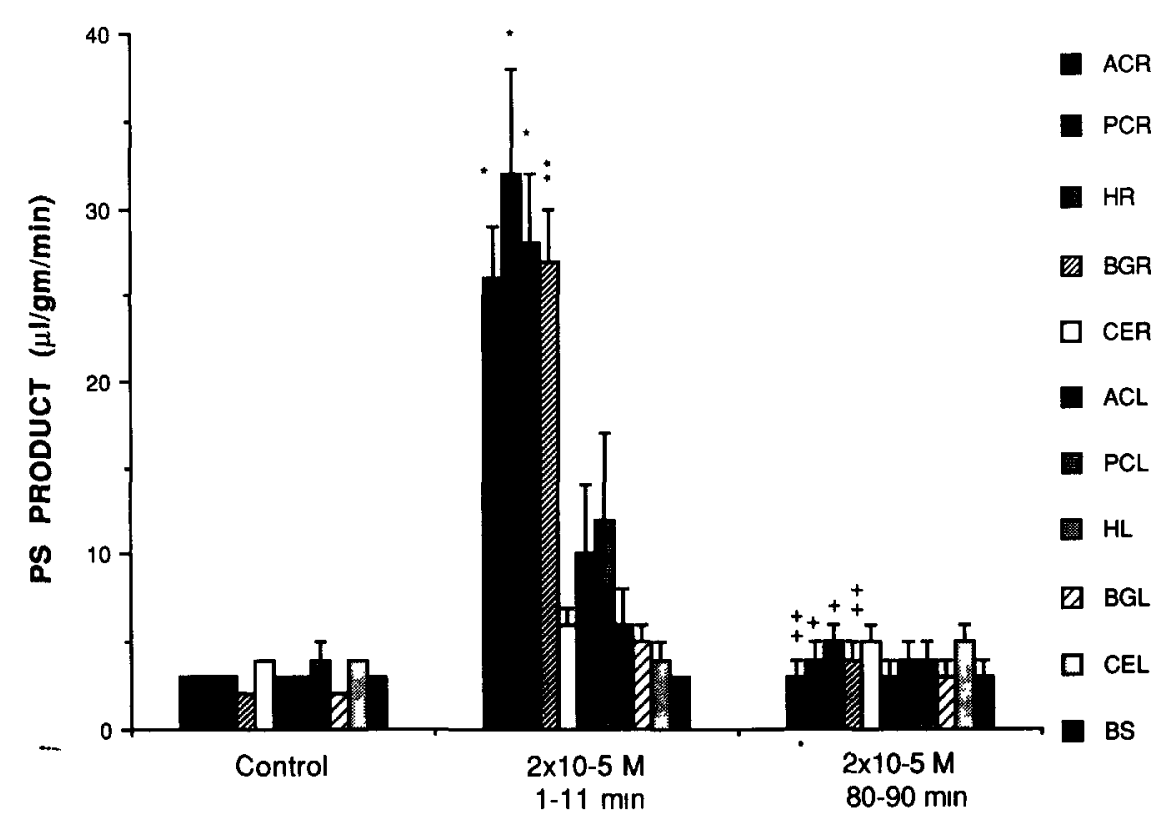

Fig 3 Reversibility of the changes in the blood-brain barrier permeability to AIB Immediately after the infusion of $2 \times 10^{-5} \mathrm{M}$ oleic acid there was a large increase in the AIB PS product, however, 80-90 min following the infusion the values returned to the control level Data points represent the means $\pm \mathrm{S}$ E M of 5 rats in each group ${ }^{*} P<005$ compared with the controls ${ }^{+} P<005$ compared with $2 \times 10^{-5} \mathrm{M}$ 1-11 min group There was no significant difference between the control and the $2 \times 10^{-5} \mathrm{M} \mathrm{80-90} \mathrm{min} \mathrm{groups}$ 
TABLE I

Physiological parameters

Values are means $\pm S E M$ of 5 anımals

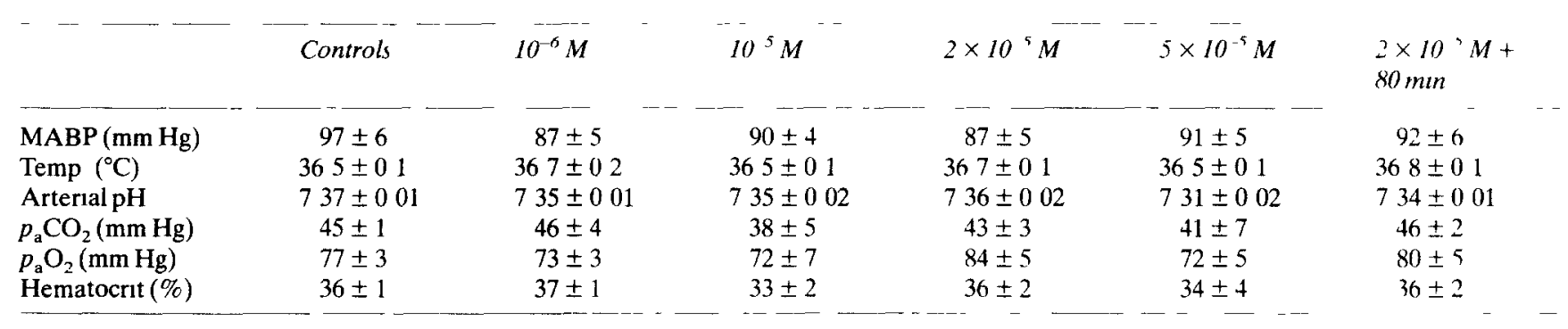

and the left cortical areas was observed after infusion of $5 \times 10^{-5} \mathrm{M}$ oleic acid (Fig 2)

The reversibility of the oleic acid-induced BBB opening to $\left[{ }^{3} \mathrm{H}\right] \mathrm{AIB}$ was examined $1-11$ and $80-90 \mathrm{~min}$ following the infusion of $2 \times 10^{-5} \mathrm{M}$ oleic acid This dose caused an initial increase in the AIB permeability of the same magnitude as a dose of $10^{-5} \mathrm{M}$, however, by $80-90$ min later, the permeability returned to the control values (Fig 3)

A higher $\left[{ }^{14} \mathrm{C}\right]$ dextran space was measured in the right sided cerebral regions parallel with the increased AIB permeability, an increase that was statıstıcally sıgnificant in the anımals perfused with $5 \times 10^{-5} \mathrm{M}$ oleic acid (Table II) This increase most likely represents extravasation of $\left[{ }^{14} \mathrm{C}\right]$ dextran as a result of the extensive BBB opening rather than a true increase in plasma volume Consequently, the values of AIB permeability at the higher doses of oleıc acid are probably underestımates of the true permeability

\section{DISCUSSION}

Oleic acid increases BBB permeability in a dosedependent, reversible manner The increase in the AIB PS product in the cortical regions of the left hemisphere and right cerebellar hemisphere can be explained as a result of cross perfusion to the contralateral hemisphere and ipsilateral cerebellar areas as indicated by the pattern of the extravasated Evans blue The heterogeneous Evans blue staining indicates an uneven distribution of areas with increased albumin permeability As the flow rate of the infusion was high, no streaming phenomena can be expected ${ }^{28}$, and the cause of the uneven appearance of the albumın staining remains to be explained

Since the BBB is created by the plasma membrane and tight junctions of the endothelial cells, the change in BBB permeability caused by oleic acid might be explained as a lipid-membrane interaction The experiments of Raz and Livne ${ }^{26}$ demonstrated that the osmotic fragility of erythrocytes is affected by oleic acid Low concentrations

\section{TABLE II}

Effect of oleic acid on $l^{14} \mathrm{C}$ dextran space

Values are means \pm S E M of 5 anımals and expressed in units of $\mu \mathrm{l} / \mathrm{g}$ ACR, PCR, HR, BGR, CER right sided anterior and posterior cortex, hippocampus, basal gangha and cerebellum, respectively ACL, PCL, HL, BGL, CEL sımılar but on the left side BS brainstem

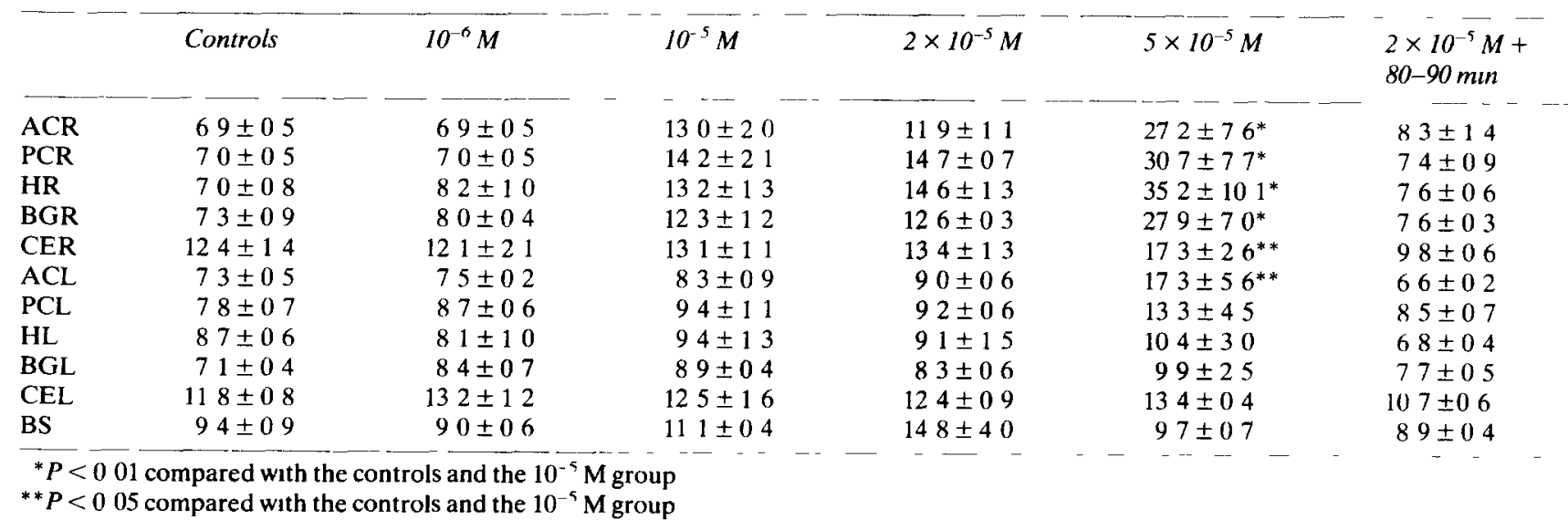


reduced the proportion of cells that were lysed while higher oleic acid concentrations $\left(10^{-5} \mathrm{M}\right.$ and higher) increased their susceptibility to osmotic shock In our experiments the same threshold concentration range of oleic acid was found to be damaging to the BBB Oleic acid is an amphiphilic substance which can induce major changes in membrane function ${ }^{10}$ At low concentrations, as a monomer, it inserts itself into the lipid membrane, changing the physical properties and physiological function of the membrane in a way that appears as a membrane-stabilızing effect ${ }^{10}$ At high concentrations, however, amphiphilic monomers aggregate into micelles which have the ability to incorporate membrane lipids into their structure The incorporation of high concentrations of amphiphıles into membranes physically disrupts the lipid bilayer and, consequently, destroys the integrity of biological membranes ${ }^{10}$ If an oleic acidmembrane interaction is responsible for the increased permeability of the BBB, it is surprising that the process is so rapidly reversible

Oleic acid is also known to be a potent activator of protein kınase $\mathrm{C}^{13,14}$, a key enzyme in mediatıng transmembrane signalıng ${ }^{16}$ The presence of protein kinases in the brain capillaries has been shown previously ${ }^{22}$ and modulation of the kınetics of protein phosphorylation by second messengers may contribute to the regulation of the BBB permeability ${ }^{21}$ Although there is only indirect evidence that protein kinase $C$ may play a role in the regulation of the BBB transport processes ${ }^{9}$, the possibility exists that oleic acid may affect the permeability of the brain vascular endothelial cells by changing protein kınase $\mathrm{C}$-induced protein phosphorylation The rapid reversibility of the oleic acid-induced BBB opening supports the view that a reversible bıochemical process is the underlying event

Recent studies ${ }^{11} 1820$ have revealed yet other biological effects that are exerted by oleic acid that could influence the permeability of the BBB Reduced synaptosomal $\mathrm{Na}^{+}, \mathrm{K}^{+}$-ATPase activity ${ }^{20}$ and inhibition of the mitochondrial oxidatıve phosphorylation ${ }^{19}$ were observed after treatment with oleic acid The release of reactive oxygen metabolites may also be involved in barrier

\section{REFERENCES}

1 Baethmann, A, Maier-Hauff, K, Schurer, L, Lange, M, Guggenbichler, C, Vogt, W, Jacob, $\mathrm{K}$ and Kempskı, O, Release of glutamate and of free fatty acids in vasogenic brain edema, $J$ Neurosurg, 70 (1989) 578-591

2 Blasberg, R G , Patlak, C S and Fenstermacher, J D, Selectıon of experımental conditions for the accurate determination of blood-brain transfer constants from single-tıme experıments a theoretical analysıs, J Cerebr Blood Flow Metab, 3 (1983) 215-225

3 Chan, P H , Fishman, R A , Caronna, J , Schmidley, J W, Prioleau, $G$ and Lee, $J$, Induction of brain edema following destruction as oleıc acıd-induced pulmonary edema can be attenuated by pretreatment with catalase and superoxide dismutase ${ }^{11}$

Oleic acid in cortical superfusion experiments performed by Unterberg et al ${ }^{29}$ was found to be without effect on the BBB of pial vessels Given intracerebrally it did not induce changes in brain water and cation levels ${ }^{3}$ The discrepancy between our results and those of others may be explained by the different route of admınıstration of the oleic acid Increased oleic acid concentrations were measured in the plasma and interstitially drained brain edema flund in cats exposed to cold injury ${ }^{1}$ and in the brain tissue following ischemia ${ }^{8,15} 30$ Our results indicate that the elevated oleic acid concentration might contribute to the disturbance of $\mathrm{BBB}$ permeability observed in these experımental models However, binding of oleic acid to albumin would normally reduce the concentration of free oleic acid in the plasma by a considerable amount In our studies, the intracarotid infusion rate was high enough to completely clear the blood from the carotid circulation on the side of the infusion Thus, there was no binding of oleic acid to albumin during the infusion and the BBB was exposed to the stated concentrations of free oleic acid We are unable to predict whether albumin-bound oleic acid would have a similar effect

In conclusion, intracarotid infusion of oleic acid increases BBB permeability in a dose-dependent and reversible fashion The procedure is well tolerated in the short term, however, neither long-term toxicity nor localızed effects leading to cellular injury, brain edema, and metabolic disturbances have been examined It is unclear at the present time whether the BBB opening induced by oleic acid results from a non-specific lipidmembrane interaction or the activation of a specific bıochemical pathway Further studies are warranted since this procedure may provide a useful clınıcal approach to modification of BBB permeability

Acknowledgements The authors thank Glona Rodriguez for her valuable secretanial support This work was supported by Grant NS 23870 from the National Institutes of Health

intracerebral injection of arachidonic acid, Ann Neurol, 13 (1983) 625-632

4 Dorovını-Zıs, K, Sato, M, Gopıng, G, Rapoport, S and Brightman, $M$, Ionic lanthanum passage across cerebral endothelium exposed to hyperosmotic arabinose, Acta Neuropathol, 60 (1983) 49-60

5 Fishman, R A , Is there a therapeutic role for osmotic breaching of the blood-brain barner?, Ann Neurol, 22 (1987) 298-299

6 Goldstein, G W and Betz, A L, Recent advances in understanding brain capillary function, Ann Neurol, 14 (1983) 389-395

7 Groothuis, D R , Warkne, P C , Molnar, P, Lapın, G D and Mikhael, M A, Effect of hyperosmotıc blood-brain barner 
disruption on transcapillary transport in canıne brdin tumors $J$ Neurosurg , 72 (1990) 441-449

8 Ikeda, M , Yoshida S Busto, R Santıso, $M$ and Ginsberg, M D , Polyphosphoinositides as a probable source of brain tree fatty acids accumulated at the onset of ischemia $J$ Neurochem 47 (1986) 123-132

9 Joo, F, Tósakı, A, Olah, Z, and Koltaı, M , Inhibitıon by $\mathrm{H}-7$ of the protein kinase $C$ prevents formation of brain edemd in Sprague-Dawley CFY rats, Brain Research, 490 (1989) 141-143

$10 \mathrm{Katz}, \mathrm{A} \mathrm{M}$ and Messineo, F C , Lipid-membrane interactions and the pathogenesis of ischemic damage in the mvocardium Circ Res, 48 (1981) 1-16

11 Katz, S A , Venkatachalam, M, Crouch, R K , Heftner, J E, Halushka, P V , Wise, W C and Cook, J A , Catalase pretreatment attenuates oleic acıd-ınduced edema in isolated rabbit lung $J$ Appl Physiol, 65 (1988) 1301-1306

12 Martz, D , Beer, M and Betz, A L , Dimethylthıorea reduces ischemic brain edema without affecting cerebral blood flow $J$ Cerebr Blood Flow Metab , 10 (1990) 352-357

13 McPhall, L C Clayton, C C and Snyderman R , A potential second messenger role for unsaturated fatty acids activation of $\mathrm{Cd}^{2+}$-dependent protein kinase, Sctence, 224 (1984) 622-625

14 Murakam1, $\mathrm{K}$ and Routtenberg, A, Direct activation of purified protein kınase $C$ by unsaturated fatty acids (oleate and arachidonate) in the absence of phospholipids and $\mathrm{Cd}^{2+} F E B S$ Lett, 192 (1985) 189-193

15 Nakano, S , Kogure, K , Abe, K and Yae, T, Ischemia-induced alterations in lipid metabolism of the gerbil cerebral cortex I Changes in free fatty acid liberation, $J$ Neurochem 54 (1990) $1911-1916$

16 Nestler, E J and Greengard, P, Protein phosphorylation in the brain, Nature, 305 (1983) 583-588

17 Neuwelt, E A and Barnett, P A , Blood-brain barrier disruption in the treatment of brain tumors In E A Neuwelt (Eds), Implicatlons of the Blood-Brain Barrier and Its Manipulations, Plenum, New York, 1989, pp 107-193

18 Ogawa, M , Yoshıda, S , Ogawa, T , Shımada, T and Takeshıta, $M$, Effect of oleic acid on mitochondrial oxidative phosphorylation in rat brain slices, Btochem Int, 17 (1988) 773-782

19 Ohno K Pettıgrew, K D and Rapoport, S I Lower limits of cerebrovascular permeability to nonelectrolytes in the conscious rat, Am J Physiol. 235 (1978) H299-H307

20 Orshı, K , Zheng B and Kuo, J F , Inhibition of Na,K-ATPase and sodium pump by protein kinase $C$ regulators sphingosine lysophosphatidylcholine and oleic aud $I$ Brol (hem 265 (1990) 70-75

21 Olah, Z, Novak, R, Lengyel, 1 Dux E and Joo, F kunetic of protein phosphorylation in microvessels solated from rat brain modulation by second messengers $f$ Neurochem 5 (1988) 49-56

22 Pardridge, W M. Yang J and Eisenberg J Blood-brain barrier protein phosphorylation and dephosphorylation, $J \mathrm{Neu}$ rochem , 45 (1985) 1141-1147

23 Rapoport, S I Blood-Brain Barrier in Phvsiolog $\}$ and Medicine, Raven New York, 1976

24 Rapoport, S I Fredericks, W R, Ohno, K and Pettıgrew $\mathrm{K} \mathrm{D}$, Quantitative aspects of reversible osmotic opening of the blood-brain barrier, Am J Phystol, 238 (1980) R421-R431

25 Rapoport, S I , Horı $M$ and Klatzo, I , Testıng of a hypothesis for osmotic opening of the blood-brain barrier, Am J Physiol, 223 (1973) 323-331

$26 \mathrm{Raz}, \mathrm{A}$ and Livne, A, Differential effects of lipids on the osmotic fragilıty of erythrocytes, Bıochim Btophys Acta 311 (1973) 222-229

27 Reese, T S and Karnovsky, M J , Fine structural localization of a blood-brain barner to exogenous peroxidase J Cell Biol 34 (1967) 207-217

28 Sarıs, S C Wright, D C , Oldfield, E H and Blasberg, R G Intravascular streamıng and variable delivery to brain followıng carotid artery infusions in the Sprague-Dawley rat, $J$ Cerebr Blood Flow Metab , 8 (1988) 116-120

29 Unterberg A Wahl, M , Hammersen, F and Baethmann, A Permeability and vasomotor response of cerebral vessels during exposure to arachidonic acid, Acta Neuropathol, 73 (1987) 209-219

30 Yoshida, S Ikeda, M , Busto, R, Santıso, M , Martınez, E and Ginsberg M D , Cerebral phosphoinositıde, triacylglycerol, and energy metabolism in reversible ischemia origin and fate of free fatty acids, $J$ Neurochem 47 (1986) 744-757 